\title{
REGRES OSADNICTWA WOŁOSKIEGO W PINDOSIE W DOBIE PRZEMIAN SPOŁECZNO-POLITYCZNYCH W TURCJI OSMAŃSKIEJ W XVIII I XIX WIEKU
}

\author{
JęDRZej PASZKIEWCZ
}

\begin{abstract}
Decline of the Vlach settlement in the Pindos region in the period of socio-political changes in Ottoman Turkey (18th-19th century). The aim of the paper is to present the conditions of a significant outflow of Vlachs from the Pindos region, which is commonly treated as one of traditional areas of the Vlachs' settlement. The migrations lasted several decades, the majority of migrants stayed on the Turkish territory, although some families migrated to other countries, especially to the central-eastern Europe. The population movements were caused by worsening security and living conditions, connected with activity of bandits and political-military turbulence in the European part of the Ottoman Turkey. First, tradesmen and craftsmen migrated, then the shepherds started looking for new pastures and locations for their settlement. As a result, the Wallachian settlers dispersed through upland-mountainous regions of Thessaly, Thrace, Macedonia, Bosnia. They settled in towns in Austria, Serbia, Greece, Bulgaria or Romania.
\end{abstract}

STRESZCZENIE. Celem artykułu jest przedstawienie okoliczności, które doprowadziły do odpływu ludności wołoskiej z rejonu gór Pindos, który jest uznawany za jeden z tradycyjnych obszarów osadnictwa Wołochów. Migracje te trwały przez dziesiątki lat, w większości odbywały się w ramach Turcji osmańskiej, ale poszczególne rodzin udawały się także poza jej granice, przeważnie do Europy środkowo-wschodniej. Wędrówki były powodowane przez pogarszający się stan bezpieczeństwa, związany z działalnością band rozbójniczych i turbulencje polityczno-militarne w europejskiej części Turcji. Motywy wędrówek miały także charakter ekonomiczny. Początkowo migrowały rodziny, żyjące z działalności handlowej i rzemieślniczej. Stopniowo z Pindosu zaczęły odpływać poszczególne klany, które szukały nowych pastwisk i miejsc osadnictwa. W rezultacie kilkusetletnich migracji, wołoscy osadnicy rozproszyli się po wyżynno-górzystych rejonach Tesalii, Tracji, Macedonii, Bośni. Osiedlali się w także miastach w Austrii, Serbii, Grecji, Bułgarii i Rumunii.

Author: Jędrzej Paszkiewicz, Uniwersytet im. Adama Mickiewicza w Poznaniu, Wydział Historii, ul. Uniwersytetu Poznańskiego 7, 61-614 Poznań, Polska, prosinac@amu.edu.pl

ORCID iD: https://orcid.org/0000-0002-7115-9284

Keywords: Vlachs, Pindos, migration, Ali pasha

Słowa kluczowe: Wołosi, Pindos, migracja, Ali pasza

Balcanica Posnaniensia. Acta et studia, XXVIII/2, Poznań 2021, Wydawnictwo Wydziału Historii UAM, pp. 207-229, ISBN 978-83-66355-84-2, ISSN 0239-4278. Polish text with summaries in English and Polish

doi.org/10.14746/bp.2021.28.28

Rejon gór Pindos odegrał zasadniczą rolę w definiowaniu współczesnej kultury i cywilizacji Wołochów. Składające się nań obszary współtworzyły na przełomie XVIII 
i XIX wieku bardzo zróżnicowany pod względem społeczno-ekonomicznym kompleks osadniczy. Osady, które ukształtowały się poza tym obszarem stanowią w rozważaniach czołowych badaczy dziejów wołoskich twórcze, ale pochodne rozwinięcie tego, co ukształtowało się właśnie w masywie Pindosu ${ }^{1}$. Szczególną uwagę historyków zwraca zwłaszcza stosunkowo duże zagęszczenie ludności wołoskiej, zamieszkującej ten rozczłonkowany topograficznie obszar, tworzącej wiele wspólnot o charakterze lokalnym. Wedle szacunkowych obliczeń Gustava Weiganda, jeszcze na przełomie XIX i XX wieku Wołosi z Pindosu liczyli blisko 50 tysięcy osób, co prawdopodobnie stanowiło około $1 / 3$ całej ludności wołoskiej, żyjącej na Bałkanach. Za serce tego rejonu niejednokrotnie uważano wówczas strefę Aspropotamos-Malakasi (wilajet Janina), gdzie znajdowało się sporo osad z ludnością wołoską. Jej koncentracja w tym rejonie była nadal duża, mimo nieodwracalnych skutków długotrwałej migracji z XVIII i XIX stulecia².

U podstaw ruchów migracyjnych z Pindosu stały załamanie ekonomiczne i zawirowania polityczno-militarne, które dały o sobie znać w europejskiej części Turcji osmańskiej na przełomie XVIII i XIX wieku. Prosperity kolejnych osad wołoskich załamywała się w następstwie dążeń miejscowych feudałów muzułmańskich. Zmierzali oni do likwidacji odrębnego statusu administracyjno-fiskalnego poszczególnych wspólnot, który zwalniał Wołochów od powinności względem osmańskich zarządców. Na przełomie XVIII i XIX wieku nasiliły się także ataki zbrojne ze strony zislamizowanych Albańczyków, spośród których rekrutowali się przedstawiciele miejscowej władzy osmańskiej ${ }^{3}$. Oddziały armatoli, organizowane przez ludność chrześcijańską, choć stosunkowo liczne, nie były w stanie skutecznie się bronić. Bezpieczeństwo wiosek wołoskich znacząco pogorszyło się w latach siedemdziesiątych XVIII wieku, gdy oddziały muzułmańskie pacyfikowały chrześcijan w związku z antyosmańskim powstaniem Orłowa (gr. Orlofika, 1770-1771). Starcia militarne spowodowały przerwanie lokalnych szlaków komunikacyjnych, prowadziły do wychodźstwa ludności.

U podstaw regresu ekonomicznego i cywilizacyjnego w rejonie Pindosu stał dramatyczny w skutkach upadek ośrodków wołoskich z rejonu Moskopola i gór Grammos (przełom lat sześćdziesiątych i siedemdziesiątych XVIII wieku), które we wcześniejszych okresach były węzłowymi ośrodkami w regionalnych powiązaniach gospodarczych oraz cywilizacyjnych. Początkowo uciekinierzy z Moskopola udawali się do osad z którymi łączyły ich więzi rodzinne lub kontakty ekonomiczne. Część asymilowała się z miejscowymi, przeważnie utrzymując się z rzemiosła lub handlu, rzadziej z hodowli zwierząt. Stopniowo zaczęto tę ludność uważać za bardziej wpływową i bogatszą część mieszkańców poszczególnych osad. Większość uciekinierów

1 Por. A. I. Koukoudis, The Vlachs: Metropolis and diaspora, Thessaloniki 2003, s. 78-81.

2 G. Weigand, Die Aromunen: ethnographisch-philologisch-historische Antersuchungen über das Volk der Sogenannten Makedo-Romanen oder Zinzaren, Leipzig 1894, t. 1, s. 154.

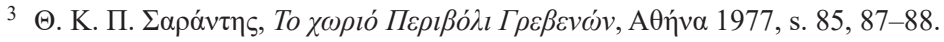


z Moskopola podążała jednak dalej, ku wschodniej i centralnej Macedonii, a stamtąd kierowała się nawet poza granice Turcji osmańskiej ${ }^{4}$. O nasilonej emigracji ludności chrześcijańskiej, która zamieszkiwała północno-wschodnie zbocza Pindosu, pisali z niepokojem zarządcy muzułmańscy. Jak informował w 1801 roku w liście do lokalnego możnowładcy Alego Paszy jeden z jego podwładnych, do osady o nazwie Naoussa, położonej w środkowej części Macedonii, nieprzerwanie napływali przybysze z wołoskiej Samariny. Pojawili się już w latach siedemdziesiątych XVIII wie$\mathrm{ku}$, wielu traktowało Naoussę jako tymczasowe miejsce osadnictwa. W międzyczasie sprowadzali także krewnych i współpracowników ${ }^{5}$.

Zawirowania osadnicze dotknęły całą ludność z tzw. wołoskiego kompleksu osadniczego w Pindosie, ale zależnie od obszaru przebiegały ze zróżnicowanym natężeniem. Z tego powodu w ogólnej charakterystyce sytuacji z przełomu XVIII i XIX wydzielić należy trzy strefy, graniczące ze sobą, usytuowane w zachodniej, południowej i północno-wschodniej części opisywanego masywu górskiego:

- rejon Zagori, określany także mianem Vlahozagoro (wilajet Janiny),

- $\quad$ osady z rejonu Greveny (wilajet Monastir),

- $\quad$ regiony Aspropotamos i Malakasi (wilajet Janiny).

\section{REJON ZAGORI}

Od XVII wieku do 1864 roku w Zagori funkcjonowała tzw. federacja Zagori, identyfikowana z kilkudziesięcioma uprzywilejowanymi osadami wołoskimi. Funkcjonowały one na podstawie przywilejów przyznanych przez władzę sułtańską. Zgodnie z nimi miejscowi chrześcijanie mieli prawo wyboru dowódcy, który reprezentował ich przed władzami, odpowiadał za sprawy całej federacji, jednocześnie rezydując w rodzinnej wiosce. Muzułmanie nie mieli prawa przybywać do Zagori, a kwestie prawnosądowe były rozstrzygane przez specjalnie do tego powołane miejscowe instytucje, odrębne od władz osmańskich. W XVIII wieku realizacja tych praw przychodziła z dużym trudem. Muzułmańscy zarządcy nierzadko łamali przywileje a chrześcijanie odpowiadali na represje, organizując oddziały zbrojne. Zdarzało się, że szukano wsparcia u lokalnych feudałów, powiązanych ze społecznościami albańskimi, zamieszkującymi tereny sąsiadujące z Zagori. Najbardziej zainteresowani sytuacją w tym rejonie byli baszowie i bejowie z Argirokastry, Tepeleny i Janiny. Poszczególne

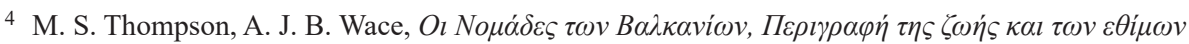

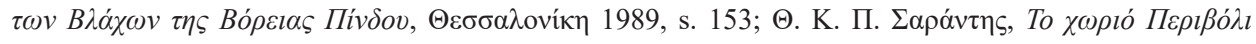

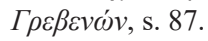

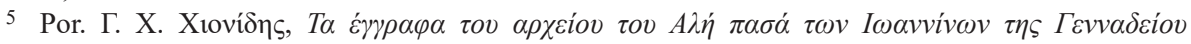

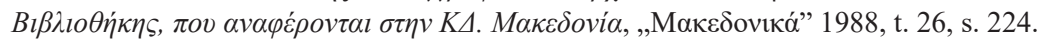




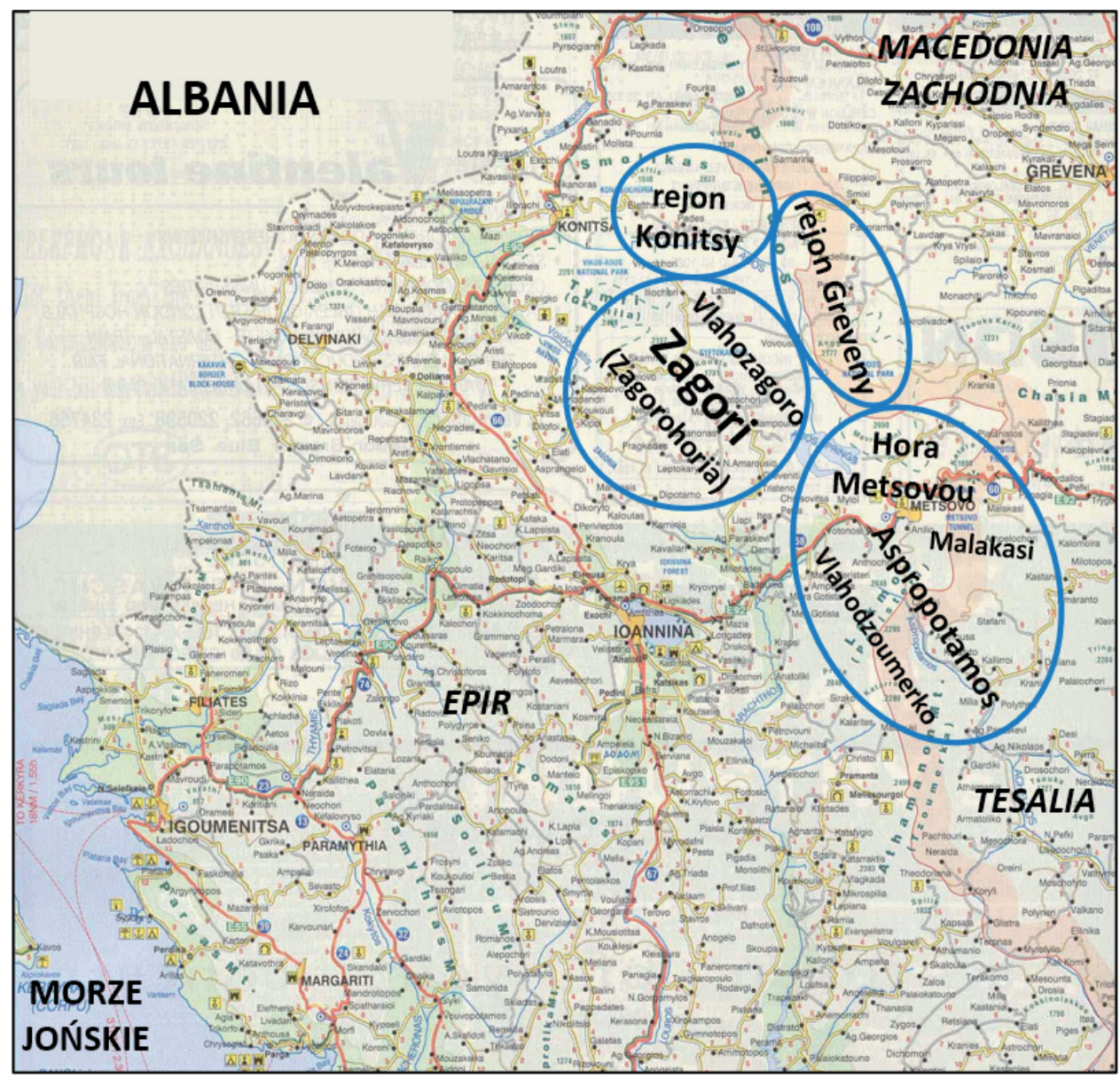

Mapa 1. Rejony tradycyjnego osadnictwa wołoskiego w greckiej części masywu Pindosu (oprac. własne na podst. mapy współczesnej, http://www.alpha-omegaonline.com/Cartes_grece/epirus.jpg)

wspólnoty z Zagori szukały tam wsparcia politycznego i pożyczały pieniądze, potrzebne do kupienia sobie bezpieczeństwa u samozwańczych dowódców muzułmańskich. W drugiej połowie XVIII wieku siedzibę zarządcy federacji Zagori przeniesiono do Janiny, co jeszcze bardziej uzależniło chrześcijan od sfeudalizowanego aparatu władzy osmańskiej ${ }^{6}$.

Pomimo tych zagrożeń poszczególne ośrodki z Zagori mogły nadal funkcjonować w oparciu o rynek lokalny. Tamtejsze osadnictwo opierało się przeważnie na małych osadach. Ludność prowadziła działalność rolną, hodowlaną, epizodycznie zajmując

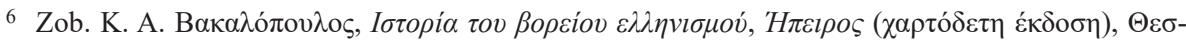

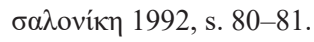


się sezonowym wypasem bydła. Od połowy XVIII wieku pasterze ze znaczniejszych i bogatszych ośrodków, takich jak Fourka czy Vovoussa, dochodzili ze swoimi stadami owiec aż do wschodniej Tesalii. W mniejszych osadach mieszana gospodarka pastersko-rolna, typowa dla osadnictwa wołoskiego, była uzupełniana przez eksploatację zasobów leśnych, produkcję smoły, węgla drzewnego i pochodni. Lokalnie rozwinęło się rzemiosło artystyczne (malarstwo ikon w Greveniti) i handlowano drewnem budowlanym (Fourka) ${ }^{7}$. Mieszkańcy Zagori tradycyjnie nie uczestniczyli w handlu dalekosiężnym, nie obracali na szerszą skalę produktami rzemieślniczymi czy związanymi z gospodarką pasterską. Tłumaczy się to stosunkowo trudnym dostępem ośrodków z tego regionu do najważniejszych szlaków handlowych i komunikacyjnych. Tamtejsze osady nie produkowały takich nadwyżek żywności, aby móc na nich zarabiać. Gospodarka miała charakter samowystarczalny, inaczej niż w przypadku rejonu południowego Pindosu czy obszarów wokół Moskopola. Zdaniem greckich badaczy, w krajobrazie gospodarczym Vlahozagoro wyróżniały się zresztą ośrodki zdominowane przez ludność greckojęzyczną. To one charakteryzowały się względnie dużym zróżnicowaniem ekonomicznym i napędzały lokalny handel. Wioski kojarzone z Włochami pozostawały w tyle, ponieważ ich ludność utrzymywała się z gospodarki pasterskiej, prowadzonej na niewielką skalę. Podobnie było z usługami transportowymi, w tej dziedzinie mieszkańcy Zagori nie byli w stanie zdystansować Wołochów z rejonu Metsova czy Greveny. Z drugiej strony, według uczonego i przedstawiciela tzw. greckiego oświecenia Athanassiosa Psalidasa (1767-1829), właśnie w Zagori, w krótkim czasie można było stworzyć oddziały zbrojne, mogące walczyć przeciwko Turkom. Uważał on zresztą, że ludność z pozostałych części Pindosu, które znajdowały się poza federacją Zagori, w zasadzie nie umiała się posługiwać bronią ${ }^{8}$.

\section{REJON GREVENY}

Odrębny kompleks, stanowiący północno-wschodnią flankę osadnictwa wołoskiego w Pindosie, ukształtował się w rejonie Greveny na podstawie czterech silnych ekonomicznie osad, zdominowanych przez gospodarkę transhumacyjną (Perivoli, Avdella, Smixi i Samarina) $)^{9}$. Szczególne miejsce ludności z tego obszaru w całościo-

7 W XIX wieku gospodarka Zagori została całkowicie zdominowana przez rolnictwo i hodowlę zwierząt. Od połowy stulecia coraz ważniejszą rolę w utrzymaniu miejscowej ludności odgrywały przekazy pieniędzy, przysyłane rodzinom przez osoby, które opuściły rodzinne wsie i wyjechały do miast lub

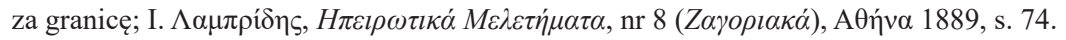

8 A. I. Koukoudis, The Vlachs, s. 172.

9 Wołoski rejon Greveny na zachodzie stykał się z Vlahozagoro i wołoskimi osadami z okolic Konitsy. Od południa znajdują się rejony Aspropotamos i Malakasi. Według opisów pochodzących z XIX wieku, kompleks osad wołoskich z rejonu Greveny dzielił się na dwie części. Pierwsza składała się z wiosek z przewagą gospodarki pasterskiej — transhumacyjnej. W drugiej dominowało stałe osadnictwo; ibidem, s. 169. 
wej charakterystyce spraw wołoskich jest związane z rolą, jaką odegrała ona w procesach osadniczych w Tesalii i Macedonii w XVIII oraz XIX wieku. Ponadto Perivoli, Avdella, Smixi i Samarina są kojarzone z najbardziej stereotypowym odbiorem Wołochów jako wędrujących pasterzy. Istotnie, większość tamtejszej ludności utrzymywała się z sezonowego, półnomadycznego wypasu zwierząt. Wspomniane wioski były zimą opuszczone przez mieszkańców i praktycznie odcięte od reszty świata. Ożywały w sezonie wiosenno-letnim, ponieważ wspólnoty pasterskie regularnie powracały do tamtejszych siedlisk i na pastwiska. Ten typ gospodarowania był dziedziczony w pokolenia na pokolenie. $Z$ drugiej strony, część mieszkańców utrzymywała się jednak $\mathrm{z}$ działalności rzemieślniczo-handlowej i transportowej, co zapewniało jej dochód bez konieczności wędrowania ze stadami. Gospodarowano także na niewielkich parcelach rolnych. Z tego względu największe „osady transhumacyjne” nigdy nie były całkowicie wymarłe $\mathrm{w}$ okresie zimowym, a w cieplejszych miesiącach stawały się ważnymi ośrodkami wymiany towarów i usług ${ }^{10}$. Poza tym w drugiej połowie XVIII wieku były miejscami tymczasowego pobytu dla wielu Wołochów migrujących $\mathrm{z}$ rejonu Moskopola w kierunku wschodnim. Jak wynika ze skąpych przekazów źródłowych, pochodzących z lat osiemdziesiątych XVIII wieku z ksiąg kościelnych z Samariny, w zasadzie cała północna część gór Pindos była wówczas pogrążona w chaosie i kontrolowana przez bandy albańskie. Ludność chrześcijańska organizowała oddziały samoobrony i jednocześnie starała się podołać rosnącym zobowiązaniom fiskalnym, nakładanym przez lokalnych zarządców. I tak, w 1786 roku mieszkańcy Samariny bezskutecznie starali się spłacić długi zaciągnięte u Osmana Beya i Yussufa Agi, zaciągając kredyt u muzułmańskich lichwiarzy. W rezultacie dług znacznie wzrósł a mieszkańcy Samariny obawiali się, że podzielą los ludności Moskopola ${ }^{11}$.

W rejonie Greveny istniało także stałe osadnictwo, w postaci miejscowości Kranja, Kallithea czy Mikrolivado (Labanitsa). W tym przypadku trudno jednoznacznie ustalić udział żywiołu wołoskiego. Wołosi żyli przemieszani z Grekami, wielu uległo hellenizacji ${ }^{12}$. Oddzielny problem dotyczy klasyfikacji wiosek zamieszkanych przez ludność chrześcijańską, którą określano mianem Kupatsari. Jeszcze na przełomie XIX i XX wieku utożsamiano ją z korzeniami wołoskimi, choć od kilku pokoleń używała języka greckiego. Mimo to według badaczy takie osady jak Elatos (Dovrani),

10 A. I. Koukoudis, The Vlachs, s. 195.

11 Wedle relacji Wace'a i Thompsona, przed migracjami z lat 1776-1830 liczba ludności Samariny sięgała 15 tysięcy osób. Dane te wydają się zawyżone, ale bez wątpienia Samarina była jedną z najludniejszych wsi w Pindosie. Kolejną znaczącą osadą w rejonie Greveny było Perivoli, które pod koniec XVIII w. liczyło prawdopodobnie ponad tysiąc osób, klasyfikowanych jako płatnicy podatku na rzecz sułtana. $\mathrm{Na}$ początku XIX wieku liczbę ludności szacowano na 300-350 rodzin, czyli około 2 tysięcy mieszkańców;

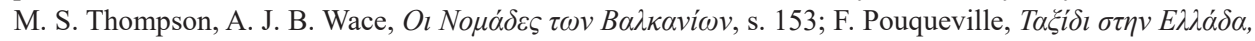

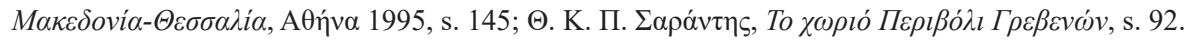

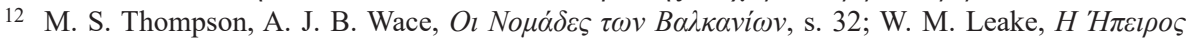
1805-1810, s. 101. 
Doxaras (Boura), Kalamitsi, Felli czy Melissi (Plessia) miały genezę wołoską i pierwotnie były zamieszkane w większości przez Wołochów ${ }^{13}$.

\section{REJON MALAKASI}

Najdłużej okres prosperity gospodarczej w XVIII wieku przeżywały osady z obszaru o nazwie Malakasi: Syrrako, Kalarites i Metsovo (wraz z podporządkowanymi mu wioskami, nazywanymi z grecka Hora Metsovou $)^{14}$. Ostatecznie, w następstwie długotrwałej destabilizacji politycznej i ekonomicznej z początku XIX stulecia, swoją pozycję ekonomiczną obroniło tylko Metsovo. Przypuszcza się, że w XVIII wieku w górzystym rejonie Malakasi odnotowano znaczący wzrost liczby ludności. Część miejscowych rodzin musiała znaleźć inne niż pasterstwo źródła utrzymania ${ }^{15}$. Transhumacyjna gospodarka pasterska, rozwijana na trudno dostępnych obszarach górskich, nie była w stanie wyżywić wszystkich rodzin. W rezultacie, w pobliskich dolinach górskich ukształtowało się stałe osadnictwo, oparte na rzemiośle, handlu i rolnictwie. Co interesujące, charakterystyczną cechą sytuacji demograficznej w rejonie Malakasi w XVIII wieku było stopniowe wyludnianie się terenów wysokogórskich. Poszczególne rody pasterskie schodziły ze stadami na niżej położone tereny, zachęcone zyskami z handlu mięsem, wełną i produktami mlecznymi. Pasterze byli zresztą niejednokrotnie do tego nakłaniani przez muzułmańskich zarządców. Ze względu na licznie występujące wówczas zbiegostwo ludności chłopskiej z czyftlików, w dolinach było dużo niezagospodarowanej ziemi, która nadawała się do wypasu. Owczy podatek, zbierany wśród pasterzy, mógł stanowić ważną formę przychodu dla właścicieli ziemi. Proces „schodzenia”, w XVIII wieku, półnomadycznych lub nomadycznych katunów z gór wiązał się także z osłabieniem pozycji ich największych konkurentów na polu pasterstwa, muzułmańskich Juruków. Ci porzucali

13 Według jednej z teorii geneza nazwy Kupatsari jest związana z wołoskim słowem kupatsu — odrosty z pnia dębu. Zdaniem G. Weiganda, wywodzi się ona ze słowiańskiego określenia rolnika lub „kopacza", co odpowiadało ekonomicznej charakterystyce tych społeczności. Przyjmuje się również, że określenie to było negatywnie kojarzone przez Wołochów-pasterzy, z pogardą odnoszących się do ludności z dolin, która porzuciła tradycyjny, wołoski styl życia. Istotnie, życie społeczno-ekonomiczne tych wspólnot odbiegało od ekonomicznej charakterystyki Wołochów zamieszkujących wyżej położone rejony górskie. W połowie XVII wieku część ludności z doliny rzeki Aliakmon, rejonu Greveny, Anaselitsy i Voio, przechodziła nawet na islam. Nazywano ją Vlahytsi, podczas gdy zislamizowaną ludność greckojęzycz-

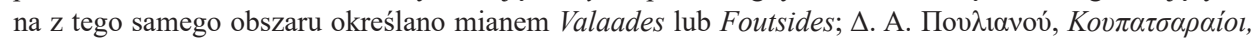

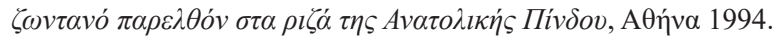

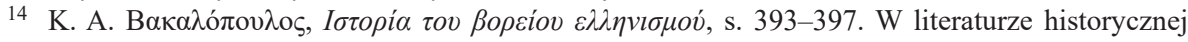
Malakasi jest traktowane jako część większego rejonu, identyfikowanego z osadnictwem wołoskim, obejmującego dolinę rzeki Aspropotamos wraz z jej dopływami (np. rzeką Pinos). Do końca XIX wieku znajdowało się tam blisko czterdzieści osad wołoskich i zmienna ilość tymczasowych lokalizacji pasterskich. Obecnie wiele z nich istnieje tylko z nazwy; A. I. Koukoudis, The Vlachs, s. 82.

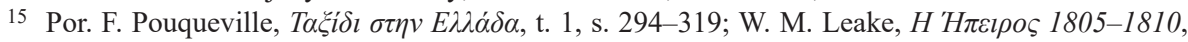
s. 102-104. 
w omawianym okresie koczowniczy tryb życia, koncentrując się na działalności wojskowej bądź rolniczej. Tym samym zaistniały okoliczności umożliwiające dynamizację wołoskiej gospodarki pasterskiej w niższych partiach gór. W warunkach wysokogórskich nadal utrzymały się powiązania oparte na formach autarkicznych. Im niżej, tym bardziej wzrastała rola zorganizowanej gospodarki transhumacyjnej, ściśle powiązanej z miejscowym handlem i rzemiosłem.

Przeludnienie, obserwowane w XVIII wieku w rejonie Malakasi, prowadziło do zróżnicowania tamtejszych powiązań gospodarczych. Wzrosła rola przetwórstwa wełny, które wcześniej nie było przedmiotem ożywionej wymiany handlowej. W miejsce produkcji domowej, nastawionej na zaspokajanie miejscowych potrzeb, w Malakasi, tak jak w okolicach Greveny czy górach Grammos powstawały swoiste konglomeraty warsztatów, kontrolowane przez miejscowe rody, nastawione na zyskowny handel wełną i jej pochodnymi. Rozwijała się wytwórczość tkanin i ubrań. Z surowej wełny owczej o nazwie skouti produkowano chociażby nieprzemakalne okrycia, połączone z kapturami (kapes), poszukiwane przez pasterzy czy żeglarzy ${ }^{16}$. Mieszkańcy, którzy nie byli bezpośrednio zaangażowani w działalność pasterską i wytwórczą, znajdowali źródło utrzymania w usługach transportowych. Początkowo poszczególne rodziny, zazwyczaj należące do mniej uprzywilejowanej części ludności, zaopatrywały rynek lokalny wykorzystując własne zwierzęta pociągowe, zwykle muły. Wynajmowano je także wspólnotom pasterskim w czasie sezonowych wędrówek stad. Stopniowo, wraz ze wzrostem liczby posiadanych zwierząt, poszczególne rody zaczęły specjalizować się w transporcie różnych rodzajów produktów. Zwykle zaczynano od dystrybucji produktów wełnianych, potem poszerzano asortyment o inne towary. Stopniowo następowała profesjonalizacja usług transportowych, które w przypadku najprężniejszych ekonomicznie rodzin uzupełniano działalnością handlową. Utrwalały się i rozwijały powiązania komunikacyjne, daleko wykraczające poza sferę lokalną. W najbardziej uczęszczanych lokalizacjach powstawały gospody, domy gościnne, a także kramy i sklepy, najczęściej prowadzone przez Wołochów. Na podstawie powiązań rodzinnych tworzyli oni zróżnicowany konglomerat ekonomiczny, złożony z różnych form aktywności. Gdy w połowie XIX wieku rola wełny w stosunkach handlowych na Bałkanach zmalała na rzecz obrotu bawełną, większość wołoskich rodów kupieckich wywodzących się z Malakasi przerzuciła się na bardziej opłacalny natenczas handel tytoniem i winem ${ }^{17}$.

Bez wątpienia aktywność handlowa Wołochów, oparta na stałym osadnictwie, wyrastała z wcześniejszych doświadczeń transhumacyjnych rodów pasterskich, oswojonych z praktyką sezonowego przemieszczania się wraz ze stadami na dużych obszarach $^{18}$. Dzięki tradycyjnej mobilności i silnym powiązaniom rodzinnym, przed-

16 Słowo skouti, używane w mowie wołoskiej, przypisuje się łacińskiemu scutum (tarcza).

17 A. I. Koukoudis, The Vlachs, s. 205.

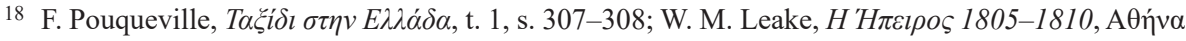
1976, s. 91. 
stawiciele wołoskich społeczności szybko zaistnieli w życiu największych ośrodków Epiru, Tesalii czy Macedonii. Za dobrą ilustrację tego procesu mogą służyć rody pochodzenia wołoskiego, współtworzące na przełomie XVIII i XIX wieku elity chrześcijańskie zamieszkujące Janinę. Jak wynika z badań genealogicznych, ich przedstawiciele przeważnie pochodzili z rejonu o nazwie Vlahodzumerko (głównie z Kalarites i Syrrako) oraz osad z Hora Metsovou. W Janinie rozwijały się takie branże, jak jubilerstwo, krawiectwo, usługi budowalne czy stolarstwo artystyczne. Krawcy wołoskiego pochodzenia byli cenieni za umiejętności haftowania złotymi nićmi i łączenia ubrań z biżuterią. Obok wytwórczości artykułów domowego użytku, wyrabianych z drewna, w Janinie i Metsovie działali rzemieślnicy specjalizujący się w zdobieniu wnętrz cerkiewnych i klasztornych. Ich sława wykraczała poza powiązania stricte lokalne ${ }^{19}$.

Można stwierdzić, że Kalarites, Syrrako czy Metsovo rozwijały się pod koniec XVIII wieku wedle podobnych zasad, co wcześniej Moskopole. Po upadku tej metropolii, kupcy z Malakasi silniej zaistnieli w powiązaniach handlowo-transportowych z Europą środkowo-wschodnią oraz wybrzeżem adriatycko-śródziemnomorskim. Kupcy wołoskiego pochodzenia działali w Dubrowniku, Neapolu, Genui, Anconie, Wenecji, Trieście, na Sardynii i Malcie. Udawali do Wiednia i Moskwy. Jak pisał na początku XIX wieku podróżujący między innymi po Malakasi Henry Holland (18121813), najważniejsze „miasta” wołoskie opierały swoją gospodarkę na przetwórstwie wełny, handlu lądowym i renomie lokalnego rzemiosła. Zwracał on uwagę na uporządkowany charakter osad, których życiem rządziły jasno określone prawa i zasady. Podkreślał, że pod tym względem pozytywnie odróżniały się one od otoczenia ${ }^{20}$. Bez wątpienia osadnictwo wołoskie o charakterze miejskim z Malakasi wyróżniało się dobrą organizacją oraz uporządkowanymi strukturami społecznymi. Potwierdzeniem prosperity były budowane w XVIII wieku cerkwie, zdobione przez lokalnych rzemieślników-artystów. W większych osadach, na przykład w Metsovie, zakładano szkoły z językiem greckim, które stawały się lokalnymi ośrodkami tzw. greckiego oświecenia, przy znaczącym współudziale nauczycieli pochodzenia wołoskiego, w tym przybyszów z Moskopola ${ }^{21}$. Jak zaobserwował William Leake, doświadczeni

19 Wśród przedstawicieli miejscowych elit z początku XIX wieku wymienia się Hristodoulosa Hadzipetrosa z Neraidohori, inspektora zajmującego się sprawami handlowymi w mieście Anastassiosa Samaritionisa, wpływowego kupca Georgiosa Tourourisa z Kalarites i lekarzy — Ioannisa Kolletisa z Syrrako (późniejszego premiera Grecji) oraz Georgiosa Tsapraslisa z Kalarites (autora jednej z pierwszych opublikowanych gramatyk mowy wołoskiej). Z Kalarites kojarzono także rodziny Lambros, Tourtouris, Sgouros i Diamitis. Wiadomo, że w czasach Alego Paszy poszczególne rodziny wołoskie miały silną pozycję w rzemiośle. Majętni Wołosi z Kalarites, Syrrako czy Metsova przesiedlali się do Janiny tak-

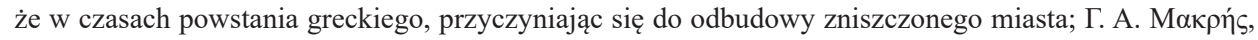

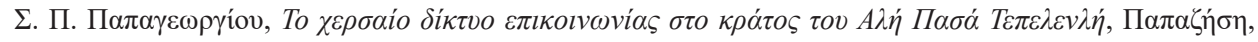
AӨńva 1990, s. 46-47, 52, 112, 173-174, 237.

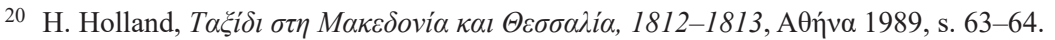

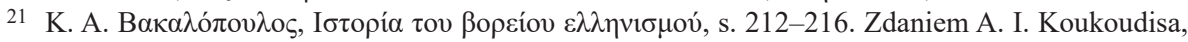
wśród działaczy niepodległościowego stowarzyszenia Filiki Etaireia (1816-1821), pochodzących z Epiru 
kupcy pochodzenia wołoskiego z Kalarites posługiwali się wieloma językami europejskimi. Byli niezastąpieni dla przybyszów z Zachodu pod względem swoich kompetencji handlowych, umiejętności nawiązywania kontaktów i przedsiębiorczości ${ }^{22}$. Francuz F. Pouqueville był pod dużym wrażeniem „harmonii i uporządkowania”, które charakteryzowało ulice Kalarites. Podkreślał on, że miejscowe przepisy zabraniały ostentacyjnego manifestowania bogactwa i służyły lokalnym producentom. Zauważał, że tamtejsze kobiety nie były „mniej miejskie” w obyciu od mężczyzn ${ }^{23}$.

\section{REJON ASPROPOTAMOS}

Największe osady z rejonu Aspropotamos, choć powiązane ekonomicznie z rejonem Malakasi, nie rozwijały się już tak intensywnie. Przeważnie były oparte na mieszanej gospodarce rolno-pasterskiej. Inaczej niż w przypadku osad w Malakasi, które miały własny samorząd, wsie z Aspropotamos były kontrolowane przez rody armatolickie. Utrzymywała się tam sztywna struktura relacji, oparta na więzach pokrewieństwa pomiędzy najważniejszymi klanami. Jak zauważył podróżnik z czasów greckiego powstania niepodległościowego Nikolaos Kassomoulis, tamtejsze wsie (Pyra, Kamaii, Tyfloseli, Gardiki) były jednak zasiedlone przez ludność zróżnicowaną ekonomicznie: kupców, pasterzy i przetwórców wełny. Kupcy, rzemieślnicy, przedsiębiorcy utrzymujący się z działalności transportowej, mieszali się z ludnością greckojęzyczną, stopniowo przejmując jej mowę i kulturęę ${ }^{24}$ Poszczególne osady rozrastały się także w następstwie migracji wewnętrznych — miejscowa ludność chroniła się tam przed bandami rozbójniczymi. Wiadomo, że na przełomie XVIII i XIX wieku największe wsie wołoskie w rejonie Aspropotamos zamieszkiwało od 300 do 500 rodzin. Największa Kastania liczyła w latach $1800-1810$ od 5 do 6 tysięcy mieszkańców

i Tesalii zachodniej, dominowali Wołosi z Metsova, Milii, Kalarites, Syrrako oraz Janiny. Przedstawiciele poszczególnych rodzin kupieckich, zaangażowani w działalność konspiracyjną, mieszkali w Odessie, Moskwie, Turnu Severin, Bukareszcie, Galati, Jassi i Stambule. Kolonia wołoska intensywnie rozwijała się na początku wieku XIX także w Aleksandrii, stając się oparciem dla miejscowej społeczności greckiej; A. I. Koukoudis, The Vlachs, s. 141, przyp. 90.

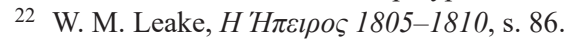

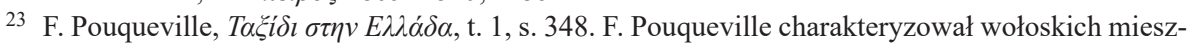
kańców jako mniej sprytnych od greckich sąsiadów, ale jednocześnie wyróżniających się stałością, ostrożnością w poczynaniach, większą wytrwałością. Byli mniej kłótliwi, niepodatni na niezgodę, intrygi i podziały. Byli także uparci oraz pamiętliwi. W ich naturze zauważał on szczerość, która odróżniała Wołochów od innych społeczności „lewantyńskich”.

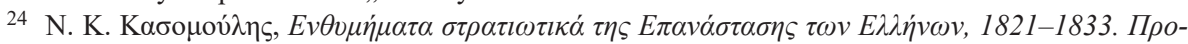

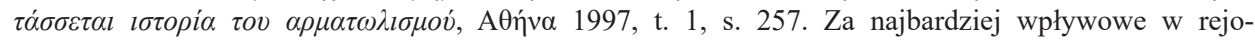
nie Aspropotamos, na przełomie XVIII i XIX wieku uchodziły następujące rody: Hadzipetrosowie (z Neraidohori), Papapolymerous i Dymakises/Papadimases (z Kastanii), Himonases (z Kranii), Hadzigakises/Hadzipetroulises (z Pertouli), Pyrgotises (z Pyrry), Ikonomous (z Klinos);

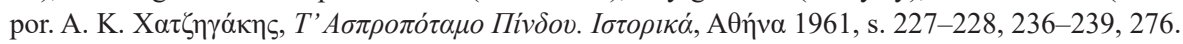


i była wielkości Metsova ${ }^{25}$. W ostatecznym rozrachunku działalność rozbójnicza zastopowała jednak rozwój ekonomiczny w Aspropotamos, Malakasi, Hora Metsovou, ponieważ wiele rodzin wołoskich zostało zmuszonych do emigracji ${ }^{26}$.

Pod koniec XVIII wieku wsie w tym rejonie były nękane przez oddziały muzułmańskich Albańczyków, ale uniknęły całkowitej dewastacji, tak jak się to stało z rejonem Moskopola. Wielkim ciosem okazały się jednak działania władz osmańskich przeciwko powstaniu Orłowa (1770-1771). Strona turecka obawiała się, że działania powstańcze inspirowane przez Rosję rozprzestrzenią się z Peloponezu do Tesalii i Epiru. Władze postanowiły odpowiedzieć także na działalność armatoli z Pindosu, którzy we wschodniej Rumelii wspierali armię rosyjską. W rezultacie władze tolerowały aktywność band, nękających wołoskie osady i pacyfikowały lokalne elity. Jak wynika z dokumentacji weneckiego konsulatu w Salonikach, w Larissie zgładzono wówczas dwadzieścia osób - liderów wiejskich społeczności wołoskich, którzy 3 marca 1770 roku przybyli na wezwanie miejscowego administratora osmańskiego. Byli wśród nich przedstawiciele najważniejszych rodów z Aspropotamos. Na rozkaz paszy wojsko osmańskie otoczyło ich i zamordowało. Nie był to odizolowany incydent. W tym samym roku władze osmańskie zgładziły w Trikali 700 osób, a w Stambule zamordowano delegatów z wołoskiej Kastanii. Poczynania władz osmańskich zlikwidowały w zarodku przygotowania do wzniecenia buntu w rejonie Aspropotamos. Z drugiej strony wśród wołoskich armatoli nasiliły się nastroje antyosmańskie, co sprzyjało zacieśnieniu współpracy z greckim ruchem narodowym ${ }^{27}$.

$\mathrm{W}$ wielu osadach rejonu Aspropotamos mowa wołoska zanikała już na przełomie XVIII i XIX wieku, w związku z obecnością coraz liczniejszej ludności greckojęzycznej. Niektórzy badacze utożsamiają proces stopniowej hellenizacji Wołochów z tego obszaru z aktywnością edukacyjną Kosmasa z Etolii (Kosmas Etolos, 1714-1779), który pod koniec XVIII stulecia głosił tam kazania i prowadził działalność oświatową. O stopniowym „wygaszaniu” mowy wołoskiej w opisywanym rejonie zadecydowały jednak przesłanki demograficzne i ekonomiczne. Przede wszystkim Grecy zajmowali miejsca zwalniane przez Wołochów, którzy poszukiwali lepszych warunków bytowych lub wymierali wskutek epidemii i katastrof naturalnych ${ }^{28}$. Postępujące przemieszanie ludności było najbardziej widoczne w dolinach rzecznych. Niekorzystnie wpłynęło to na ogólną kondycję mowy wołoskiej, która była wypierana przez grekę we wszystkich dziedzinach życia codziennego miejscowych społeczności. Choć jeszcze w XIX wieku w wielu miejscowościach, gdzie współistniały obok siebie wspólnoty grecka i wołoska, kultywowane były odrębne obyczaje, młodsze pokolenia nie uczyły się już języka wołoskiego. Jak odnotowywali podróżnicy przemierzający ten

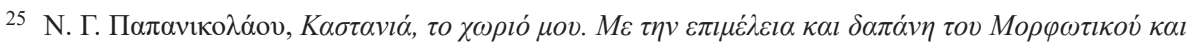

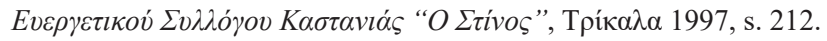

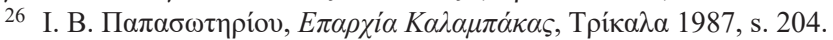

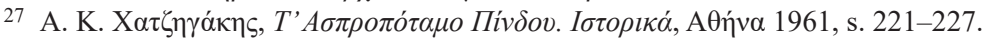

28 Ibidem, s. 322. 


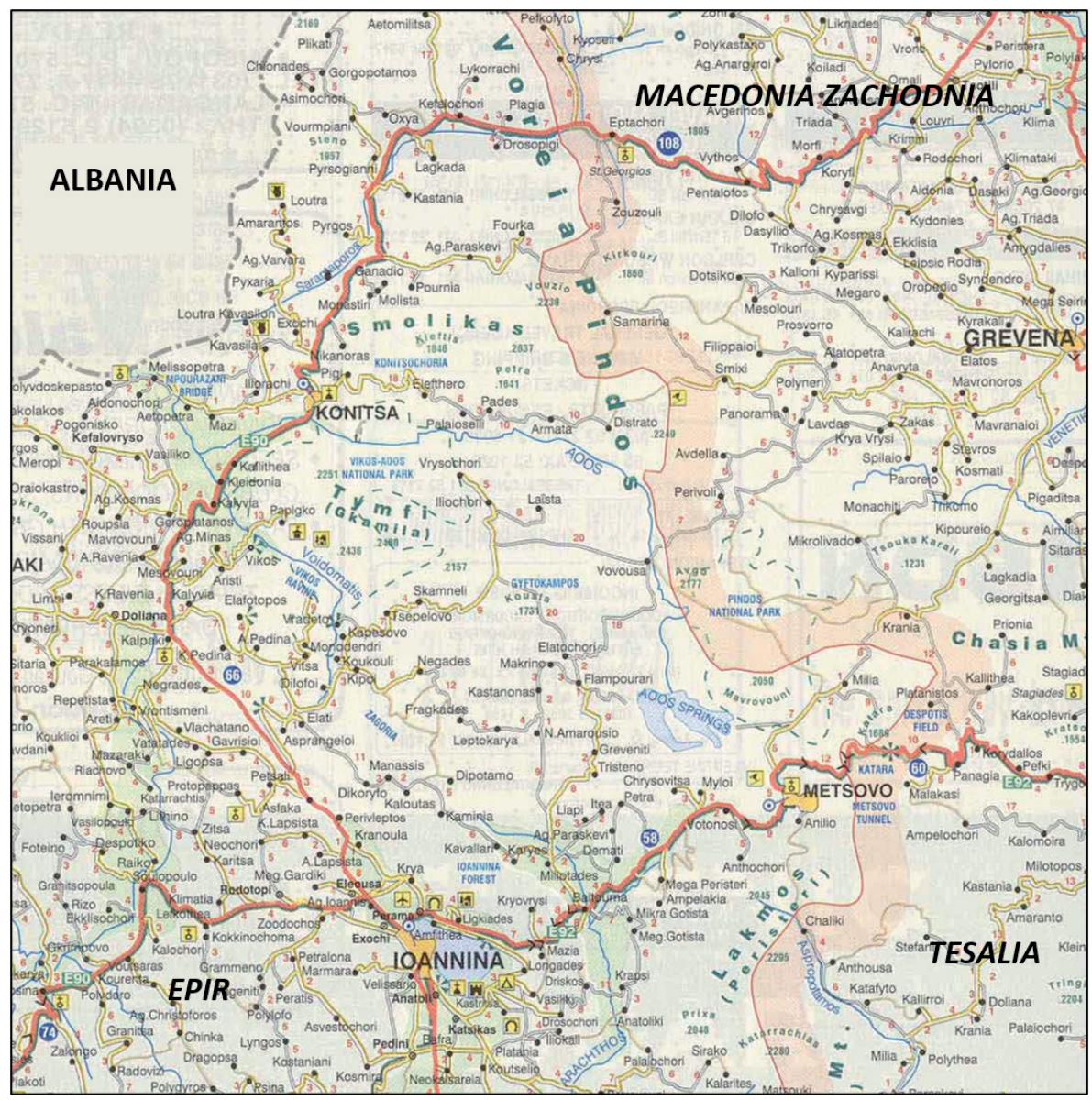

Mapa 2. Osady o tradycjach wołoskich w greckim rejonie Pindosu, wskazane w tekście (na podst. mapy współczesnej; http://www.alpha-omegaonline.com/Cartes_grece/epirus.jpg [dostęp: 13.12.2021])

rejon Aspropotamos, Wołosi prowadzący osiadły tryb życia nie znali mowy rodzimej nawet od kilku pokoleń. Z drugiej strony utożsamiali się jednak z różnymi elementami tradycji pasterskiej. Opisywanej sytuacji nie mogło odmienić sezonowe osadnictwo z udziałem pasterzy wołoskojęzycznych, schodzących na czas zimy z Pindosu. Poszczególne klany pasterskie z Samariny czy Perivoli, kultywujące mowę przodków na co dzień, zazwyczaj izolowały się od ludności osiadłej. Po wchłonięciu Tesalli przez Grecję i wytyczeniu w 1881 roku nowej granicy państwowej, grecko-tureckiej, pasterze zaczęli omijać Aspropotamos. Migrowali w kierunku masywu Olimpu, który znajdował się pod jurysdykcją osmańską do 1913 roku $^{29}$. 


\section{OKOLICZNOŚCI MIGRACJI LUDNOŚCI Z PINDOSU W XIX WIEKU}

W literaturze przyjmuje się, że największe migracje ludności wołoskiej, do których doszło w pierwszej połowie XIX wieku, przyczyniły się do zmniejszenia liczby mieszkańców Pindosu nawet o ponad 1/3. Przebiegały one w dwóch fazach, w latach 1820-1822 i 1822-1830.

Za początek migracji o dużym nasileniu przyjmuje się okres ostatecznej konfrontacji pomiędzy Alim Paszą a wojskami sułtańskimi. Nastąpiła ona pod koniec 1820 roku, w następstwie zdobycia przez siły sułtańskie twierdzy w Janinie. Uciekinierzy obawiali się, że miejscowi wrogowie Alego będą brali odwet na jego sprzymierzeńcach, wśród których znajdowały się wpływowe rody wołoskie z Zagori, Aspropotamos czy Samariny. Wśród migrujących były całe rodziny, aktywne na polu ekonomicznym. Druga fala migracji (1822-1830) stanowiła kontynuację wcześniejszych ruchów ludnościowych i jest w literaturze przedmiotu identyfikowana z rozwojem greckiego ruchu narodowego oraz wydarzeniami powstania niepodległościowego Greków (18211831). Choć walki powstańcze koncentrowały się na Peloponezie, wśród wołoskich armatoli, którzy rezydowali w Pindosie, silne były wpływy greckich konspiratorów. Ich wyrazem był dość liczny udział epirskich i tesalskich Wołochów zarówno w konspiracji, jak i starciach powstańczych. Aby zniechęcić miejscową ludność do wspierania powstańców, administracja sułtańska utrzymała dotkliwe kontrybucje żywności na rzecz oddziałów stacjonujących w Epirze, obowiązujące za czasów Alego Paszy. Miejscowym odbierano zwierzęta juczne, które wykorzystywano do transportu broni i żywności.

W pierwszym rzędzie migracje dotyczyły osób żyjących z handlu i rzemiosła, które nie miały racji bytu na obszarze ogarniętym walkami, plądrowanym przez bandy rozbójnicze. Należy dodać, że w sierpniu 1820 roku Ali Pasza ze względów strategicznych nakazał spalić chrześcijańską dzielnicę handlowo-rzemieślniczą w centralnym ośrodku regionu, Janinie, aby lepiej przygotować miasto do obrony przed oddziałami sułtańskimi. W tym przypadku migranci, poszukujący nowych miejsc do zamieszkania i działalności gospodarczej, zwykle udawali się do miejscowości, gdzie przebywali oraz pracowali już członkowie ich rodzin ${ }^{30}$. Oprócz tego migrowały także całe wspólnoty pasterskie, które wraz ze stadami kierowały się na tereny niepodlegające władzy Alego Paszy. Najczęściej uciekinierzy z Pindosu starali się dostać na zachodni brzeg Wardaru (Axios), który znajdował się poza zasięgiem satrapy z Janiny. Z kolei pasterze zimujący w Tesalii, nękani przez wojska paszy i oddziały osmań-

30 Porównanie liczb, odnotowanych przez F. Pouqueville'a (1812) i P. Aravandinosa (1856) pozwala ocenić skalę dotyczącą zmniejszenia liczby rodzin wołoskich w poszczególnych miejscowościach: w Vovoussie z 150 do 42 rodzin, Greveniti z 200 do 142, Neo Amaroussi 100 do 69, Makrino z 100 do 62, Elatohori z 200 do 129, Vryssohori z 200 do 136, Iliohori z 150 do 138. Wzrost liczby ludności zaob-

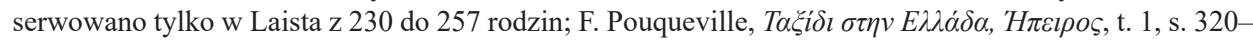

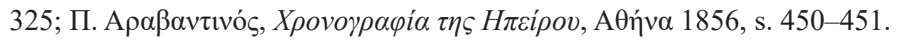


skie, szukali nowych terenów pod wypas w masywie Olimpu, Vermio lub na wybrzeżu egejskim.

Kontakty pomiędzy Alim Paszą (1741-1822) a przedstawicielami klanów wołoskich z Pindosu sięgały prawdopodobnie połowy lat osiemdziesiątych XVIII wieku. W 1785 roku sułtan powołał go, jako lennika, na naczelnego dowódcę korpusów odpowiedzialnych za bezpieczeństwo na drogach i przejściach górskich w Tesalii. Możnowładca osmański szybko nawiązał relacje z liderami społeczności wołoskiej, najwcześniej w rejonie Aspropotamos. Jego celem było spacyfikowanie działalności czet atakujących karawany i oddziały wojskowe, a w dalszej perspektywie pełne podporządkowanie regionów, zamieszkanych między innymi przez ludność wołoską. Ali Pasza starał się osłabić istniejący system powiązań pomiędzy poszczególnymi rodami, sprawującymi faktyczną kontrolę nad osadami w Aspropotamos, Malakasi, Zagori, rejonie Greveny a także w masywie Olimpu ${ }^{31}$. Przez blisko dwadzieścia lat, począwszy od 1788 roku, stopniowo przejmował władzę nad Tesalią i Epirem. Zacieśniał kontrolę nad prosperującymi osadami wołoskimi, pozbawiając je przywilejów i nakładając kontrybucje. Jego celem było włączenie odrębnych administracyjnie i ekonomicznie wsi wołoskich do swoich posiadłości ziemskich (czyftlików). Jak pisał w 1814 roku F. Pouqueville, Wołosi znaleźli się w jarzmie satrapy z Janiny, który ich korumpował i zachęcał do donosicielstwa ${ }^{32}$. Około 1790 roku wezwał on wołoskich przywódców z Aspropotamos do Janiny i zażądał poddania się jego władzy. Oczekiwał bezwarunkowego podporządkowania. Chcąc pokazać swoją siłę, wtrącił do więzienia i torturował oponentów, rozkazał także wygnać z Kastanii wpływowego kupca Yannisa Dimakisa, który przestrzegał rodaków przed działaniami satrapy. Aby zmusić wołoskie elity do podległości, Ali Pasza wspierał lub tolerował ataki na wsie ze strony lojalnych wobec niego oddziałów dowodzonych zarówno przez muzułmanów, jak i chrześcijan. Około 1794 roku miał on wydać polecenie jednemu z dowódców, Yussufowi Arapowi, aby ten nękał osady, które okazywały opór wobec nacisków ze strony władz. Z kolei w sierpniu 1809 roku oddział dowodzony przez służącego Alemu Georgiosa Karaiskakisa, późniejszego powstańca greckiego, puścił z dymem pół osady o nazwie Polythea. W 1816 roku dowódca czety rozbójniczej o imieniu Katarahias zdewastował Haliki, gdy mieszkańcy nie mogli opłacić swojego bezpie-

31 Wydaje się, że najdłuższą tradycję miały kontakty Alego Paszy ze starszyzną wołoską z Aspropotamos. Sięgały one czasu, gdy rywalizował on o wpływy z innymi dostojnikami albańskimi. Gdy jego życie znajdowało się w niebezpieczeństwie, znalazł on schronienie właśnie wśród wołoskich mieszkańców Aspropotamos. Miał zostać przyjęty przez przywódców tamtejszych rodów, np. przez Dimakisa z Haliki lub Hadzipetrosesa z Neraidohori. W tym samym czasie poznał także kaznodzieję i mni-

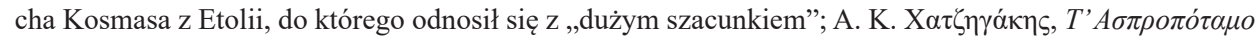

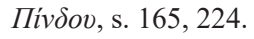

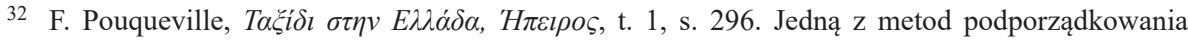
miejscowej ludności, stosowanych przez Alego Paszę, było aranżowanie małżeństw mieszanych pomiędzy przedstawicielami klanów wołoskich a rodzinami dowódców wojskowych, podlegających satrapie; A. I. Koukoudis, The Vlachs, s. 126. 
czeństwa. Ali Pasza miał ponoć dobre relacje z wołoskimi przywódcami Haliki, mimo to nie powstrzymał swojego podwładnego i sojusznika Katarahiasa przed złupieniem osady $^{33}$.

W opinii F. Pouqueville'a, Ali Pasza cieszył się jednak poparciem części rodów wołoskich, co doprowadziło do nasilenia rywalizacji pomiędzy poszczególnymi klanami ${ }^{34}$. Ponieważ na dworze Alego w Janinie działało kilku notabli mających związki z Samariną, część badaczy uważa, że ta największa osada z rejonu Greveny mogła być uprzywilejowana ekonomicznie przez władcę $e^{35}$. Ali oczekiwał od tamtejszych rodów, że nie będą współpracować z jego albańskimi konkurentami. W zamian respektował odrębne, tradycyjne prawa wsi. Za jego zgodą Samarina przejęła kontrolę nad pobliską osadą rolniczą, zamieszkaną przez Słowian (Helimodi/Hilimodi). Z drugiej strony, aby zapewnić posłuch, Ali Pasza sprowadził na swój dwór zakładnika, członka wpływowego rodu Hadzimatisów. W 1808 roku torturował i skazał na śmierć mnicha Dimitriosa z Samariny, oskarżając go o przygotowywanie buntu ${ }^{36}$.

Atakowani mieszkańcy uciekali przed agresorami, opuszczając ziemie znajdujące się pod władzą paszy. Emigrację potęgowało przekształcanie wsi w czyftliki, poddane bezpośredniej władzy możnowładcy i jego krewnych. Ci, którzy pozostali na miejscu byli obciążeni wysokimi podatkami i chronili się ze swoimi rodzinami oraz stadami w górach. Rodziny utrzymujące się z handlu i rzemiosła najczęściej podążały w kierunku wschodnim i północnym, na wybrzeże egejskie oraz ziemie macedońskie. Tak było w przypadku większości osad Hora Metsovou, którym odebrano odrębność administracyjną w 1795 roku. Wyemigrowało wówczas wiele rodzin kupców i rzemieślników. Osiedlały się one przeważnie w Salonikach i mniejszych ośrodkach wschodniej Macedonii. Z kolei część mieszkańców Metsova dotarła do dzisiejszego Płowdiw lub zasiliła społeczności wołoskie, zamieszkujące miasta pod władzą Habsburgów i w Rosji. Migracja z Metsova kierowała się także na północ, do Kruševa, Monastiru, Malovište ${ }^{37}$.

Emigrowano w większych grupach, na które składały się całe wspólnoty pod przewodnictwem liderów poszczególnych klanów. Tak było w przypadku rodu Hadzipetrosów z Neraidohori. Na jego czele stał Gousios Hadzipetros, wzbogacony na handlu wełną. W 1812 roku jego rodzina znalazła się na skraju bankructwa, obciążona domiarami na rzecz paszy. Ciężar emigracji całego klanu, który nie chciał poddać się władzy feudała, spoczął na dwóch synach Gousiosa, Yannakisie i Hristodoulosie. Osiedlili się oni w Serres, skąd prowadzili interesy w Turcji i poza nią. Wkrótce Hristodoulos (1799-1869) wyjechał wraz z częścią tamtejszych kupców do Wiednia.

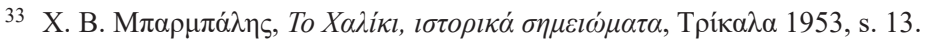

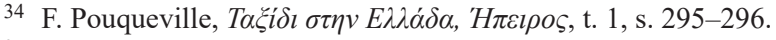

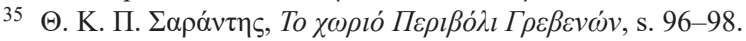

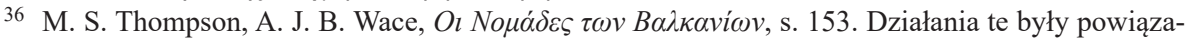
ne z działalnością armatolika Papathymiosa (Thymiosa) Vlahavasa (1760-1809). Po śmierci Alego Paszy, Dimitrios został uznany za męczennika; A. J. Valpy, The Pamphleteer, 1822, t. 21, s. 173-175.

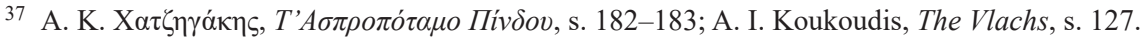


Tam zaangażował się w działalność komitetu wspierającego grecką niepodległość, miał ponoć namawiać Napoleona do wsparcia tej idei przez Francję. Krótko potem, w 1817 roku, Hristodoulos pojawił się na dworze Alego Paszy w Janinie, jako jego sekretarz i propagator współpracy z ruchem greckim ${ }^{38}$.

Jak wspomniano już wcześniej, Ali Pasza rządził podbitą ludnością za pomocą restrykcyjnych domiarów podatkowych i okolicznościowych kontrybucji. Wymownego przykładu dostarczają losy niewielkiej, ale prężnej ekonomicznie osady handlowej w Aspropotamos (Vlahozoumerka), Kallarites. Jak podają źródła, początkowo mieszkańcy zostali obciążeni domiarem o wartości 14 tysięcy piastrów, który z czasem wzrósł do 45 tysięcy piastrów. Aby spłacić zobowiązania, musieli zadłużyć się u kredytodawców, współpracujących z dworem paszy. Z kolei ludność niewielkiej osady Matsouki musiała ją opuścić, nie mogąc sprostać długom zaciągniętym u lichwiarzy z Janiny. Część mieszkańców udała się do rejonu Agrafa. Ci, którzy pozostali, poprosili w 1809 roku paszę, aby odkupił od nich osadę. Ponieważ nadal musieli płacić wysokie podatki, ostatecznie opuścili domostwa około 1818 roku i rozproszyli się po Arcie, Tesalii oraz środkowej Macedonii ${ }^{39}$.

Migracje w kierunku wschodnim prowadziły do wyludnienia większości wiosek w Aspropotamos. Taki los spotkał ważną niegdyś osadę wołoską o nazwie Malakasi, położoną na pograniczu Epiru i Tesalii. Od XIX wieku nazwa Malakasi jest używana w literaturze przedmiotu na określenie jednej z części większego regionu historycznego Zagori, położonego na pograniczu Epiru i Tesalii. Gdy Tesalia została włączona do Grecji w 1881 roku, w tym subregionie utrzymywał się jeszcze zwarty obszar tradycyjnego osadnictwa wołoskiego, oparty na wsiach Anilio, Votonossi i Milia. W XIX wieku funkcjonowała także położona bardziej na południe grupa sześciu osad, identyfikowanych z osadnictwem wołoskim (Matsouki, Kalarites, Mystras, Syrrako, Paiohori Syrrakou, Vathypedo). W odróżnieniu od skupiska wsi greckich, identyfikowanych z nazwą Tsoumerka, tworzą one niewielki subregion Vlahotsoumerko ${ }^{40}$.

Postępujący w pierwszej połowie XIX wieku proces stopniowej depopulacji obszaru tradycyjnego wołoskiego osadnictwa w Pindosie, można prześledzić na przykładzie kilku miejscowości, które odgrywały ważną rolę w ekonomice regionu jeszcze pod koniec XVIII wieku. I tak, problemy położonej w Zagori wsi o nazwie Vovoussa zaczęły się w pierwszych latach XIX wieku, gdy mieszkańcy musieli zapożyczyć się celem spłacenia podatków u syna Alego Paszy, Saliha. Udało im się co prawda uregulować dług, ale jednocześnie szybko stracili odrębny status administracyjny i zostali wcieleni do czyftliku. Z 1814 roku pochodzą informacje, że nadal dobrze prosperująca handlowo Vovoussa, zamieszkana przez blisko 270 rodzin, została dotknięta epidemią, w dodatku była regularnie najeżdżana przez bandy wołoskie i albańskie.

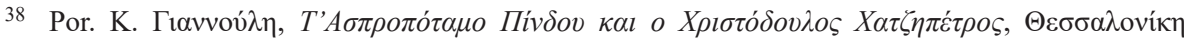
1992.

39 A. I. Koukoudis, The Vlachs, s. 123, 124.

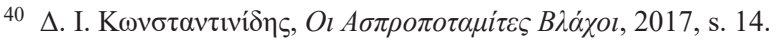


Ataki odbywały się za przyzwoleniem Alego Paszy, który dążył do przejęcia pełnej kontroli nad wsią. Po 1817 roku Vovoussę miało opuścić od 120 do 150 rodzin, uznawanych za jej elitę ekonomiczną i społeczną. Udały się one w kierunku wschodniej Macedonii i wschodniej Rumelii (Peštera, Rodopy, Haskovo koło Płowdiwu). W 1824 roku, w związku z walkami o twierdzę powstańców greckich w Missolounghi, pozostali we wsi mieszkańcy musieli świadczyć służbę transportową na rzecz armii sułtańskiej. Osiemnastu zginęło podczas walk, reszta uciekła ze swoimi zwierzętami, pozostawiając ładunki wojskowe. W obawie przed osmańską zemstą za porzucenie służby, wyruszyli oni do środkowej i wschodniej Macedonii. Podążali szlakiem przetartym wcześniej przez krewnych i współmieszkańców z Vovoussy. W nowych miejscach osadniczych szybko integrowali się z Wołochami z innych rejonów Pindosu i mieszkańcami greckojęzycznymi, stając się częścią elit chrześcijańskich. Tak było chociażby w większych miejscowościach, Serres czy Iraklia w środkowej Macedonii ${ }^{41}$. Sama Vovoussa całkowicie opustoszała w latach trzydziestych XIX wieku.

Podobnie potoczyły się losy ważnej osady z Zagori, Fourki, znanej z dobrze zorganizowanego pasterstwa transhumacyjnego i działalności transportowej. Tam także mieszkańcy byli systematycznie nękani przez ataki uzbrojonej ludności albańskiej i musieli płacić za swoje bezpieczeństwo miejscowym bejom z rodu Frashëri oraz bejom z rejonu Dangelli. Fiaskiem zakończyły się próby szukania wsparcia u sułtana i zdobycia pieniędzy na spłatę długów. Fourka została przekształcona w czyftlik w 1793 roku, co doprowadziło do exodusu najbardziej przedsiębiorczych mieszkańców. Ucieczek nie powstrzymało nawet przywrócenie Fource przez Alego Paszę, w 1793 roku, odrębnego statusu. Mieszkańcy, w tym także rodziny zajmujące się pasterstwem, osiedlili się przeważnie w Macedonii zachodniej (rejon Kozani).W połowie XIX wieku wioska była uznawana za opuszczoną ${ }^{42}$. Uciekinierów nie powstrzymywało nawet to, że ich działania były uznawane za bezprawne. Władze osmańskie, jak i Ali Pasza, bezskutecznie próbowały siłą zawracać migrantów do rodzinnych wiosek. I tak, niepowodzeniem zakończyły się próby władz tureckich przesiedlenia do Zagori części ludności ze wschodniej Macedonii. Kolumny przesiedleńców, którzy pokonywali trasę do Zagori pod nadzorem osmańskich strażników, dotarły tylko do zachodniej Macedonii. W okolicach Ptolemaidy eskortowani rozpierzchli się, a strażników obrabowano lub zabito. Przesiedleńcy nie chcieli wracać do Zagori, uważając, że nie znajdą tam warunków umożliwiających przeżycie ich rodzinom ${ }^{43}$.

W latach 1817-1819 doszło do całkowitej depopulacji osady Avdella (rejon Greveny), zamieszkanej przez pasterzy transhumacyjnych. Do jednej z najbardziej spek-

41 A. I. Koukoudis, The Vlachs, s. 215-219, 222-223. Po dotarciu do okolic Serres, w Macedonii środkowej, migranci z Vovoussy rozproszyli, osiedlając w pobliskich wsiach. Wśród ich potomków tradycja pochodzenia z Vovoussy utrzymywała się do lat dwudziestych XX wieku. Ze względu na odrębne tradycje osadników tych, żyjących z rolnictwa, rzemiosła lub handlu, określano w XIX wieku jako „osiedlonych Wołochów".

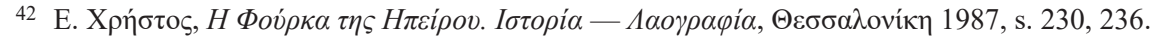

43 A. I. Koukoudis, The Vlachs, s. 221. 
takularnych ucieczek doszło tam prawdopodobnie latem 1819 roku, w wyniku decyzji podjętej na głównym placu wioski przez przedstawicieli najważniejszych rodów z Avdelli i okolic (rody Bardalexis, Zeana Dassou, Veros, część rodu Karayannis). Starszyzna rodowa postanowiła szukać nowych pastwisk zimowych poza obszarem władzy Alego Paszy. Zamiast do Tesalli, gdzie znajdowały się tradycyjne tereny wypasu, skierowano stada ku rzece Wardar. W migracji, która prawdopodobnie miała charakter exodusu, uczestniczyło blisko 200 rodzin, ich wędrówka odbywała się pod przywództwem rodu Badralexis ${ }^{44}$.

Losy upadku jednej z czterech wołoskich wiosek transhumacyjnych z rejonu Greveny, Perivoli, związane były z represjami politycznymi wobec rzeczników greckiej idei niepodległościowej. W latach dziewięćdziesiątych XVIII wieku władze osmańskie zdekonspirowały niepodległościową działalność Rigasa Feraiosa (Velestinlis/Velistinles; 1797-1798), prawdopodobnie wołoskiego pochodzenia, który był powiązany z tamtejszymi klanami pasterskimi. Jego aktywność polityczna ściągnęła na pasterzy z Perivoli, przebywających na zimowym wypasie w tesalskim Velestino, krwawe represje. Turcy zabili członków jego rodziny, zniszczyli osadę ${ }^{45}$. Mieszkańcy Perivoli byli także skonfliktowani z Alim Paszą, dlatego na początku XIX wieku około 200 rodzin, na czele z przywódcą o imieniu Exarchos, wyruszyło ze stadami w kierunku wzgórza Galičica/Petrino, na północny zachód od jezior Prespa. Ponieważ tamtejsze pastwiska okazały się niewystarczające, zapuszczali się dalej na północ (Resen, Malovište, Magarevo, Nižepole, Monastir). Po upadku paszy i zakończeniu wojny o niepodległość Grecji, niektóre stada pasterzy z Perivoli powróciły do wschodniej Tesalii na wypas zimowy (zbocza góry Kissavos), ale omijały Perivoli. Wieś całkowicie opustoszała wraz z wybuchem powstania niepodległościowego ${ }^{46}$.

Około 200 rodzin opuściło także transhumacyjną osadę Smixi (rejon Greveny). Powodem było włączenie wsi do czyftliku Alego Paszy. Wedle tradycji, migranci ze Smixi przybyli do wschodniej Macedonii, prawdopodobnie do Eleftheroupoli koło

44 Pierwsze dwa lata migranci z Avdelli mieli spędzić na górze Kerkini/Belesica koło Ano Poroia (sezon letni) i półwyspie Kassandra, we wschodniej części półwyspu Chalcydyckiego (sezon zimowy). W 1822 lub w 1826 ród Badralexis otrzymał zgodę na osiedlenie się na zboczach Vermio, w miejscach opuszczonych przez ludność grecką. Przybysze stawiali chaty pasterskie, zakładając osady Seli, Skoutina czy Maroussia. Osiedlali się także w niżej położonych rejonach, w pobliżu osad Weria i Naoussa;

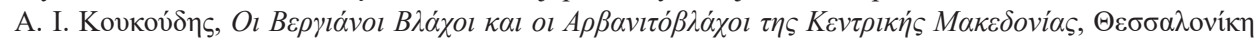
2001, s. 98-105.

45 R. Feraios prawdopodobnie pochodził z jednej z tamtejszych rodzin, które tradycyjnie spędzały zimę w wołoskiej miejscowości Velestino, położonej we wschodniej części Tesalii. Wedle innego przekazu, jego ojcem był Zissis Rizos z Vovoussy, a matką niejaka Hadzistetyiou z Grammousty;

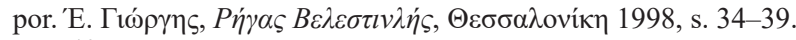

46 Emigranci z Avdelli wykorzystywali także szałasy pasterskie w rejonie Pirinu (obecnie w Bułgarii). Podążali także w kierunku Rodopów. We wszystkich przypadkach mieszali się oni z Wołochami przybyłymi z Grammousty (góry Grammos). W XX wieku wielu potomków migrantów z Avdelli zamieszkiwało greckie miasta: Serres, Iraklia, Drama, Doksato, Kavala, Stavroupoli, Ksanthi, Komotini; A. I. Koukoudis, The Vlachs, s. 328, 330, 338-339. 
Kavali, gdzie zasiedlili m.in. osadę, którą później nazwano Vlahika. Korzystała z pastwisk położonych na wzgórzach Pangaion, ich obecność odnotowano także na zboczach Kerkini, nieopodal obecnej granicy grecko-bułgarskiej i w okolicach Serres ${ }^{47}$.

Regres demograficzny i ekonomiczny na ziemiach zamieszkanych przez Wołochów pogłębiły wydarzenia związane z grecką insurekcją niepodległościową. Na obszarze tym aktywni byli agenci powstania, zarówno pochodzenia greckiego, jak i wołoskiego. Ideę niepodległościową poparły przeważnie zmilitaryzowane środowiska armatoli, liderzy wiejskich społeczności prezentowali bardziej zdystansowane stanowisko wobec haseł zaangażowania się w walkę z Turcją osmańską. Z drugiej strony, jak wynika ze wspomnień autorstwa jednego z weteranów powstania, zresztą wołoskiego pochodzenia, Nikosa K. Kasomoulisa (1795-1872), większa część Wołochów podzielała jednak greckie idee niepodległościowe ${ }^{48}$. Wśród osad wołoskich które najbardziej ucierpiały w następstwie wydarzeń powstańczych, wymienia się Syrrako i Kalarites, dokąd po upadku Alego Paszy zbiegło wiele rodzin korzystających z jego opieki. W czerwcu 1821 roku obie osady zadeklarowały poparcie dla powstania greckiego a miesiąc później armia osmańska przypuściła zwycięski szturm. Ludność schroniła się w górach Agrafa i Zoumerka. Część dotarła do Missolunghi, zasilając obsadę twierdzy obleganej przez Turków w 1826 roku. W latach trzydziestych w Kalarites mieszkało około 26 rodzin, spośród blisko 500, które przebywały tam do 1821 ro$\mathrm{ku}^{49}$. Choć ludność Metsova raczej nie uczestniczyła w walkach powstańczych, siły osmańskie zablokowały osadę, kontrolując przejście górskie w Zygos. Oddziały Hursita Paszy wzięły na zakładników część miejscowej starszyzny, aby uniemożliwić zaangażowanie się mieszkańców w walki po stronie powstania. Ostatecznie zakładników zabito. Metsovo padło także ofiarą ataków ze strony progreckich armatoli, którzy działali w górach i oskarżali mieszkańców o sprzyjanie stronie tureckiej. Część osady, około 180 domostw, została spalona przez powstańców w 1821 ro$\mathrm{ku}^{50}$. W Aspropotamos wiele wiosek wołoskich (m.in. Pertouli, Neraidohori, Pyrra) zostało zniszczonych w 1823 roku przez współpracujące z Turcją oddziały albańskie, dowodzone przez niejakiego Selihtara Boda/Poda. Przez kolejne lata cały teren Aspropotamos znajdował się w ruinie. Jak relacjonował około 1826 roku uczestnik powstania Nikos Kassomoulis, mieszkańcy żyli w górskich lasach, w szałasach, czekając na lepsze czasy. Większość uciekła na południe. Opustoszałe wsie były łatwymi celami dla rabusiów, którzy stali się wówczas plagą ${ }^{51}$.

W charakterystyce wpływu greckich wydarzeń powstańczych na sytuację ludności wołoskiej z Pindosu należy wspomnieć o znanej i popularnej wśród Greków pieś-

47 Ibidem, s. 341-343.

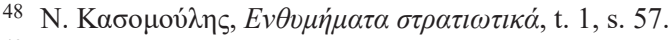

49 Mieszkańcy Syrrako i Kalarites pojawili się także na wyspach Korfu i Zakynthos oraz po włoskiej stronie wybrzeża adriatyckiego. Nieliczni wrócili do domu, gdy władze osmańskie ogłosiły amnestię;

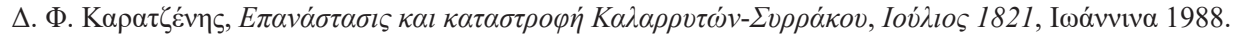

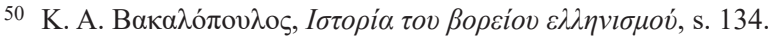

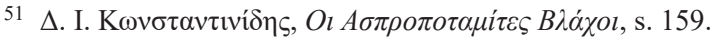


ni pt. „Chłopcy z Samariny”, która współcześnie jest wykonywana podczas uroczystości narodowych i różnych imprez folklorystycznych. Przywołuje onawspomnienie obrońców Missolunghi. Zgodnie z ludową tradycją, w obronie twierdzy uczestniczyło około 150 młodych mężczyzn z Samariny pod dowództwem kapitana Mihosa Florosa. Do domu powróciło zaledwie 33. Silne związki między wpływowymi rodami z Samariny a Grecją zaowocowały także przygotowaniami do wzniecenia w rejonie Greveny buntu przeciwko Osmanom w latach pięćdziesiątych XIX wieku ${ }^{52}$. Po wybuchu wojny krymskiej (1853-1854) greccy agenci prowadzili agitację wśród chrześcijan z Tesalii, Epiru i południowej części Macedonii. Na apele o zorganizowanie antytureckiego powstania odpowiedział Theodoros Ziakas, pochodzący z jednego z rodów z rejonu Greveny. Powstanie miało wybuchnąć wiosną 1854 roku, gdy wołoscy pasterze schodzili z zimowych pastwisk w Tesalii. Powstańców zwołano na dzień 20 maja w okolice tesalskiej osady Deskati. Stawiła się większość rodów pasterskich, pochodzących z Samariny, Perivoli, Avdelli, Smixi, Fourki, Grammousty i Aetomilitsy. Stworzono prowizoryczny obóz, a dowódcy postanowili poczekać na wyjaśnienie się sytuacji i nie podejmować żadnych gwałtownych ruchów wobec sił tureckich. Dowódca osmański, Mehmed aga z Greveny, uznał pasterzy za buntowników i zażądał od nich pieniędzy. Pasterze zostali spacyfikowani po krótkiej walce z lepiej uzbrojonymi oddziałami tureckimi. Wydarzenia te, określane mianem bitwy pod Fyllourią, stały się synonimem rzezi na ludności wołoskiej przez siły osmańskie. Zdziesiątkowane rody wołoskie rozpierzchły się w różnych kierunkach. Tylko część wróciła do swych wiosek.

Bez wątpienia ludność wołoska, emigrująca w XIX wieku z całego obszaru Pindosu, znacząco wpłynęła na ukonstytuowanie się współczesnego demograficznego i cywilizacyjnego obrazu równiny Tesalii. I tak, wielu Wołochów z Aspropotamos, Hora Metsovou i wiosek z rejonu Greveny zasiliło greckojęzyczne społeczności miejskie Trikali czy Karditsy. Ponadto część ludności pasterskiej, która w następstwie zmian granicznych została odcięta od zimowych siedlisk na płaskowyżu tesalskim, przenosiła się do Grecji, łącząc z krewnymi i zasilając wcześniej istniejące osady wołoskie. Obecność Wołochów, którzy w drugiej połowie XIX wieku przeważnie prowadzili osiadły, rolniczy tryb życia, przy dużym udziale hodowli zwierząt, odnotowano na przełomie XIX i XX wieku na obszarze całej Tesalii — w rejonach miast Trikala, Karditsa, Larissa, Tyrnavos, Elassona, Farsala, Agia Volos czy Almyros ${ }^{53}$. Na podstawie ruchów ludności pasterskiej, pochodzącej przeważnie z rejonu Greveny, w pierwszej połowie XIX wieku ukształtowało się znaczące skupisko osadnicze Wołochów transhumacyjnych w rejonie gór Vermio w centralnej Macedonii. Mowa o wsiach Kato Vermio wraz z osadami satelickimi o nazwach Volada i Maroussia, a także o Xirolivado. Pierwszorzędne znaczenie w ukształtowaniu się tego nowego obszaru osadniczego Wołochów odegrali przybysze z Avdelli, którzy w początkowym okre-

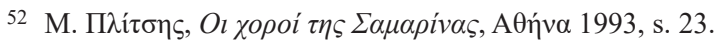

53 A. I. Koukoudis, The Vlachs, s. 450. 
sie osadnictwa stanowili prawdopodobnie większą część tamtejszej ludności. Jeszcze na początku XX wieku, mieszkańcy wołoskiego pochodzenia zamieszkujący rejony Vermio i okolice miasta Weria (Veroia), wykorzystywane do wypasu zimowego, byli powszechnie nazywani „Avdellitas”. W tym samym czasie Wołosi z Kato Vermio i Xirolivado stopniowo porzucali działalność pasterską na rzecz rolnictwa i rzemiosła. Część przenosiła się do niżej położonych osad, zdominowanych przez Greków. Na początku XX wieku w Imathii, Koumarii, Werii, Naoussie, Katerini czy Pierii działało wielu rzemieślników i kupców o wołoskich korzeniach, spokrewnionych z pasterskimi rodami transhumacyjnymi ${ }^{54}$.

Przełom XVIII i XIX wieku był w dziejach społeczności wołoskich, żyjących pod panowaniem osmańskim czasem poważnych przewartościowań w życiu poszczególnych wspólnot terytorialnych. Dokonywały się one pod wpływem długotrwałych, wielokierunkowych migracji ludności, niepokojów społeczno-politycznych i wydarzeń wojennych. Najliczniejsze wspólnoty wołoskie, które funkcjonowały w rejonie Pindosu (Vlahozagoro, dolina rzeki Aspropotamos, rejon Greveny), od początku XIX wieku ulegały depopulacji. Proces ten był związany z narastającym fiskalizmem ze strony przedstawicieli władz osmańskich, sporami politycznymi i konfliktami zbrojnymi, które przetaczały się przez tereny zasiedlone przez poszczególne społeczności. Destabilizacja ekonomiczna i brak poczucia bezpieczeństwa zmuszały ludność, nie tylko wołoską, do migracji, najczęściej w kierunku wschodnim i północnowschodnim. Część Wołochów, związanych z działalnością handlową, opuściła obszar Turcji osmańskiej, osiedlając się na terenie Monarchii Habsburgów oraz kształtujących się w XIX wieku państwach bałkańskich (Serbia, Rumunia). Większość pozostała pod władzą osmańską, ulegając rozproszeniu. W nowych warunkach, zdominowanych przez ludność greckojęzyczną lub Słowian, osadnicy wołoscy zwykle funkcjonowali jako mniejszość. Ulegali obcej presji demograficznej i kulturowej. Istniejące wśród nich zróżnicowanie, oparte na lokalnych tożsamościach terytorialnych czy klanowych, pogłębiło się wraz z intensyfikacją procesów asymilacyjnych. Migranci albo stapiali się z obcą ludnością, albo utrzymywali pewne odrębności w postaci własnych obyczajów, tradycji ustnych czy sposobu gospodarowania.

Z punktu widzenia obserwatorów europejskich i greckich z XIX wieku, proces stosunkowo szybkiej asymilacji Wołochów z innymi grupami etniczno-językowymi zależał od charakteru działalności ekonomicznej. W rejonie Pindosu, utożsamianym przez wielu historyków z „kolebką" wołoskiego osadnictwa, najszybciej politycznie i językowo asymilowały się, to znaczy hellenizowały się wioski, których ludność przez kilka pokoleń zajmowała się rolnictwem. W wyżej położonych osadach, które były trudno dostępne, a w okresie zimowym odizolowane od otoczenia, Wołosi dłużej zachowywali poczucie odrębności. Nawet jeśli w XIX wieku wielu z nich utożsamiało się z grecką narodowością, w sferze lokalnej podkreślali swoją odrębną, pastersko-wołoską charakterystykę. Utrzymanie tej świadomości było możliwe tak długo,

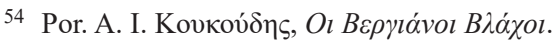


jak długo istniał specyficzny dla tych społeczności system odniesień społecznych, powiązany ze wspólnotami pasterskimi i gospodarką transhumacyjną. W ośrodkach rolniczych spuścizna wołoska, identyfikowana $\mathrm{z}$ rytmem życia pasterskiego, odstawała od codziennego życia mieszkańców uprawiających ziemię. Poza tym wioski były bardziej otwarte na otoczenie zewnętrzne, częściej pojawiali się tam „obcy” w postaci osadników, kolonistów, wojska. Proces asymilacji postępował wraz ze wzrostem liczby małżeństw mieszanych. Należy zwrócić uwagę, że w ośrodkach, gdzie dominowała gospodarka pastersko-hodowlana, małżeństwa z osobami spoza miejscowych wspólnot jeszcze w połowie XIX wieku były rzadkością. Wynikało to ze zdystansowanego nastawienia wołoskich górali wobec osób z zewnątrz, nawet jeśli posługiwały się one podobnym językiem. Na utrzymanie dystansu wobec otoczenia wpływały także więzi terytorialno-klanowe, styl życia i miejscowe obyczaje. Z kolei rolnicze społeczności wołoskie przechowały elementy kultury wołoskiej, ale najczęściej bez udziału komponentu językowego. Ponadto zacierały się granice kulturowe i słabły więzi z macierzystymi wspólnotami. Negatywną konsekwencją procesów migracyjnych było rozproszenie społeczności pierwotnie uformowanych w rejonie Pindosu. W rodzinnych stronach pozostawali ludzie starsi i mniej zaradni ekonomicznie. Prowadziło to zarówno do regresu gospodarczego, jak i przerwania ciągłości osadniczej.

\section{BIBLIOGRAFIA}

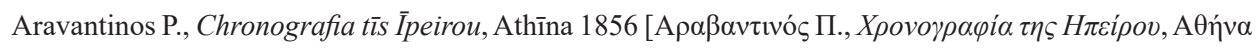
1856].

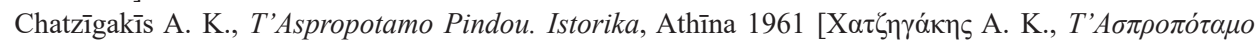

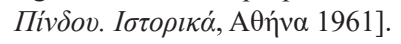

Chionidīs G. Ch., Ta eggrafa tou archeiou tou Alī pasa tōn Iōanninōn tīs Gennadeiou vivliothīkīs, pou

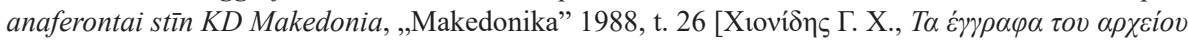

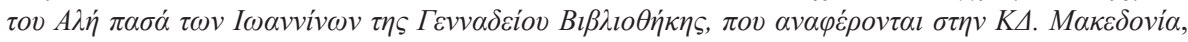

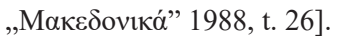

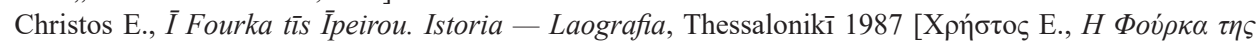

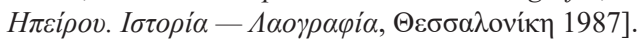

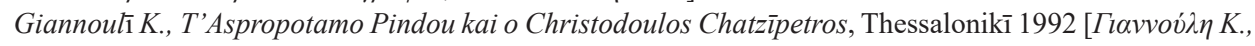

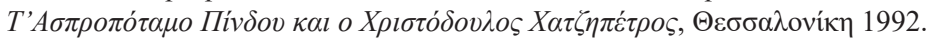

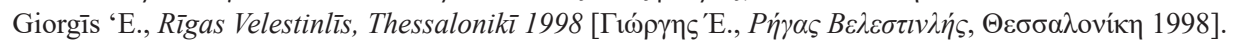

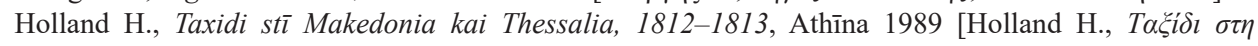

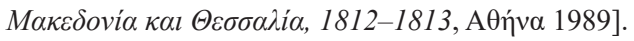

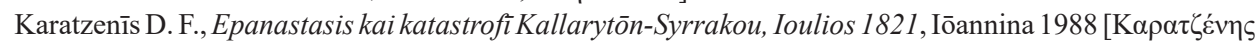

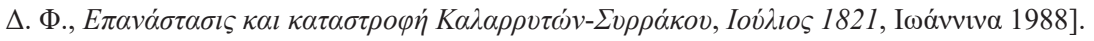

Kasomoulīs N. K., Enthymīmata stratiōtika tīs Enanastasīs tōn Ellīnōn, 1821-1833. Protassetai istoria

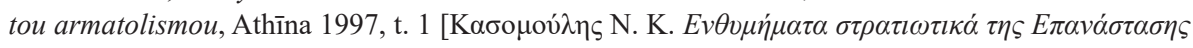

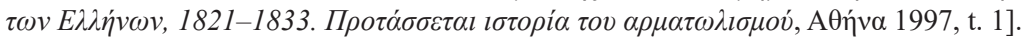

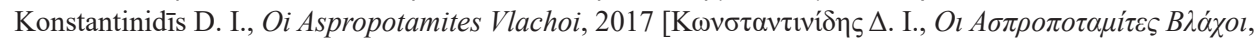
2017].

Koukoudis A. I., The Vlachs: Metropolis and diaspora, Thessaloniki 2003.

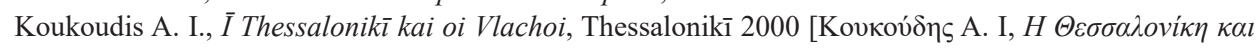

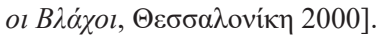


Koukoudis A. I., Oi Vergianoi Vlachoi kai oi Arvanitovlachoi tīs Kentrikīs Makedonias, Thessalonikī

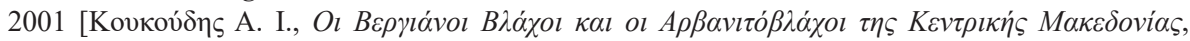

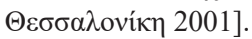

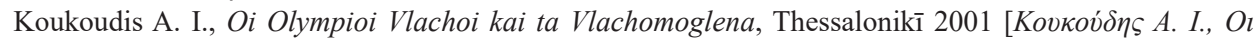

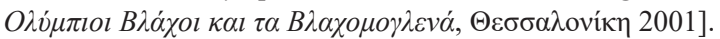

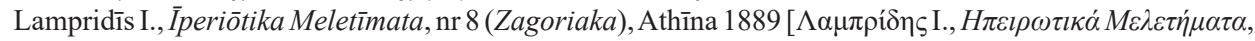

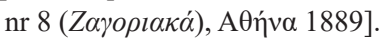

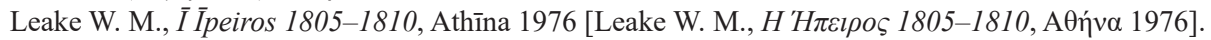

Makrīs G. A, Papageōrgiou S. P., To chersaio diktyo epikoinonias sto kratos tou Alī Pasa Tepelenlī, Athīna

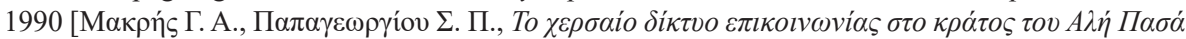

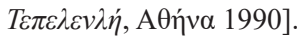

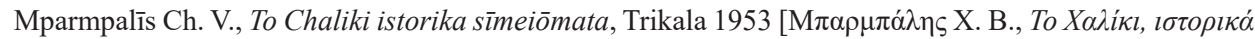

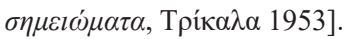

Papanikolaou I. G., Kastania, to chōrio mou. Me tīn epimeleia kai dapan̄i tou Morfotijou kai Euergetikou

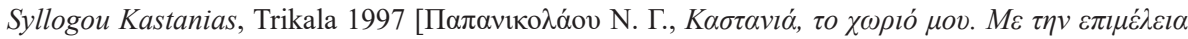

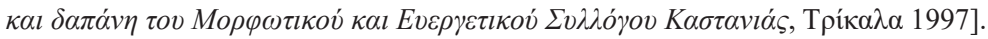

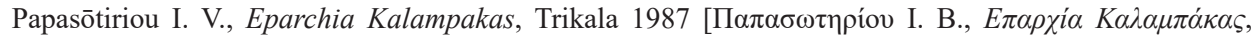

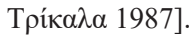

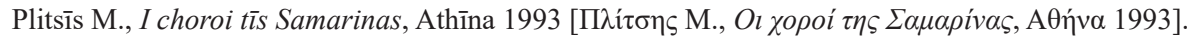

Poulianou D. A., Koupatsaraioi, Zōntano parelthon sta riza tis Anatolikīs Pindou, Athīna 1994 [Поvגıavoú

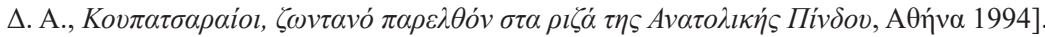

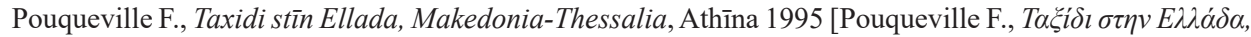

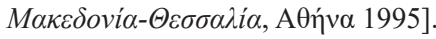

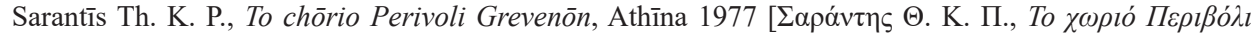

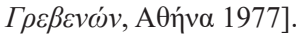

Thompson M. S., Wace A. J. B., Oi Nomades tōn Valkaniōn. Perigrafì tīs zōis kai tōn ethimōn tōn Vlachōn

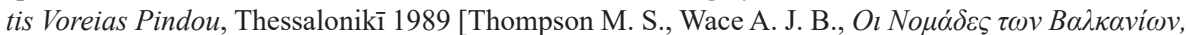

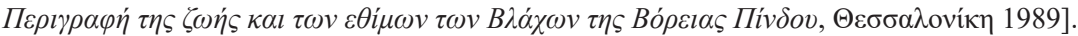

Vakalopoulos K., O Voreios Ellīnismos kata tīn prōimī fasī tou Makedonikou agōna (1878-1894),

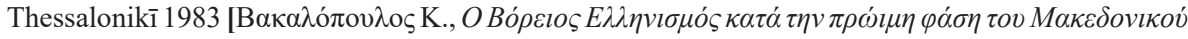

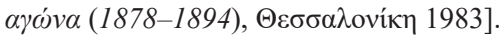

Vakalopoulos K. A., Istoria tou voreiou ellīnismou, Ipeiros (chartodetī ekdosī), Thessalonikī 1992

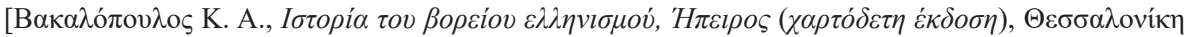
1992].

Valpy A. J., The Pamphleteer, 1822, t. 21.

Weigand G., Die Aromunen: ethnographisch-philologisch-historische Antersuchungen über das Volk der Sogenannten Makedo-Romanen oder Zinzaren, Leipzig 1894, t. 1-2.

Winnifrith T., Shattered eagles, Balkan fragments, London 1995. 